\title{
The Potential of Lazar Canyon [Serbia] as a Geotourism Destination: Inventory and Evaluation
}

\author{
Tomić NemanjaA \\ Received: April 2011 | First Revised: April 2011 | Second Revised: August 2011 | Accepted: August 2011
}

\begin{abstract}
The aim of this paper is to present the Lazar's Canyon area as a potential geotourism destination. The region of eastern Serbia, where this canyon is located, has the highest concentration of geosites in the country. This makes the Lazar's Canyon area a good candidate for becoming a Geopark in the future. Despite it's rich geodiversity, this region lacks the infrastructure and qualified staff required for further development of the area. The main purpose of this paper is the tourist evaluation of Lazar's Canyon and a proposed inventory of attractive geosites in the surrounding area. The evaluation method is partially based on the needs and views of tourists that visited the site and gave their opinion through a survey that was conducted during that visit. The paper also briefly discusses and analyses the existing problems and necessary criteria that are preventing this area from becoming a Geopark at the moment.
\end{abstract}

Key words: Lazar's Canyon, evaluation, geotourism, geoheritage, geopark, Serbia

\section{Introduction}

Lazar's Canyon is located in the region of eastern Serbia (Figure I), within ten kilometers from the town of Bor and it is the deepest and the longest canyon in the region. This territory is very rich with numerous canyons, caves and pits that are located in a relatively small area. These geosites are excellent representatives of this area's geodiversity. Geoheritage sites usually include all geological, geomorphological, pedological and distinct archaeological values created during the formation of the Earth's crust (Djurović, Mijović, 2006). All of these values are present in the area of Lazar's Canyon which makes this teritorry excellent for the development of geotourism in the future. This type of tourism is emerging as a new global phenomenon (Dowling, 2008) and it falls within the category of special interest tourism mainly focused on geology and the formation of landscapes (Hose, I995, 2005). It is defined as: "The provision of interpretative facilities and services to promote the value and societal benefit of geological and geomorphological sites and their materials, and to ensure their conservation, for the use of students, tourists, and other casual recreationalists." (Hose, 2003, 2008). This definition clearly shows that the main focus of geotourism is on interpretation, promotion and conservation, which are all key elements for the development of geotourism on any territory. In this case, (geo)conservation means the "active management of something to ensure it's quality is retained " unlike preservation which usually implies no change at all (Burek, Prosser, 2008). When defining geotourism, two opposing conceptions emerge. According to some scholars the term geotourism refers to the relationship between geography and tourism. This definition encompasses all natural and human components of an area where geology and geomorphology present the support for the ecological systems and socio-economic development and culture. According to others, the "geo" part in geotourism refers to geology and geomorphology. In this conception, geotourism is a form of natural area tourism that specifically focuses on landscape and geology and their promotion, interpretation and conservation through appreciation and education (Newsome, Dowling, 2010). Geotourism also represents a good opportunity for the development of sustainable tourism as it is strongly connected to sustainable management principles by balancing economic, ecological and social aspects as an integrated whole. Because of this, it's

\footnotetext{
A Department of Geography, Tourism and Hotel Management, Faculty of Science, University of Novi Sad, Trg Dositeja Obradovića 3, 21000 Novi Sad, Serbia; e-mail: airtomic@gmail.com
} 


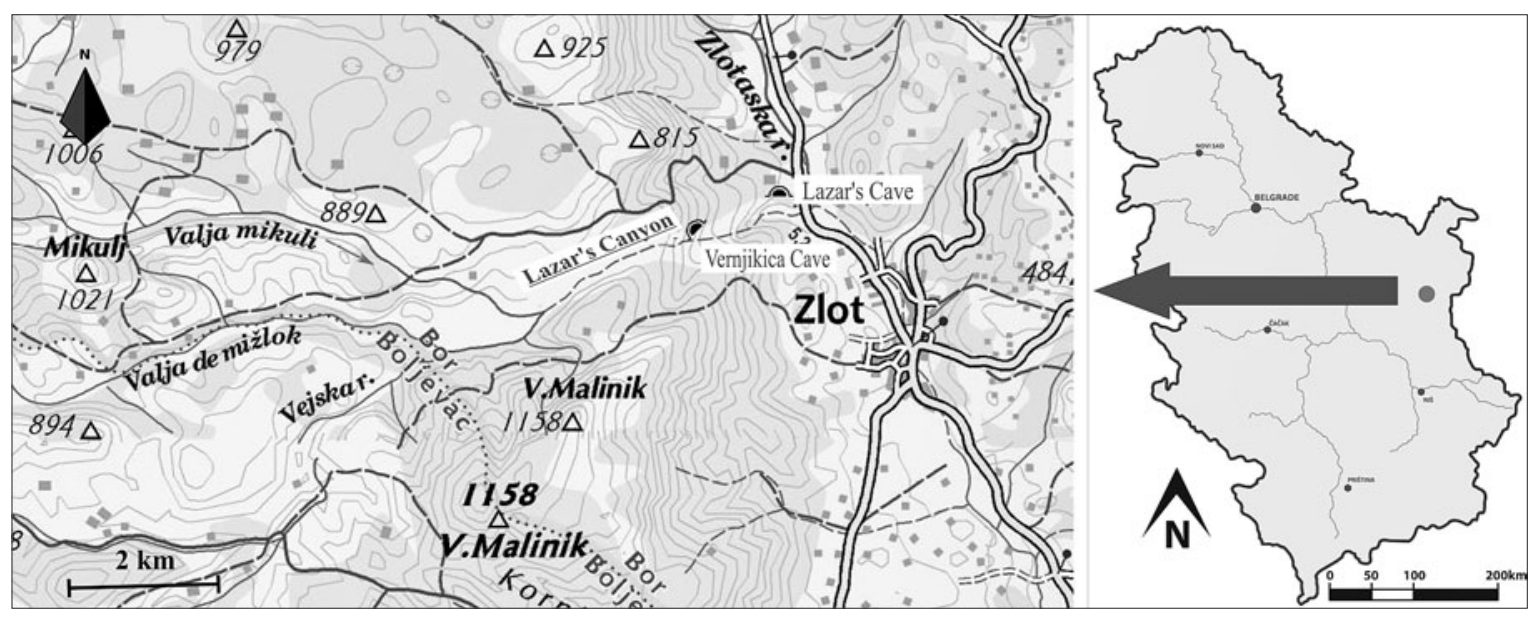

Figure 1. Location of study area

Source: Magicmap Interactive Atlas of Serbia V1.0, 2007, modified

development should be funded by the government and incorporated into the economy (Dowling, Newsome, 20I0). Unlike several other forms of sustainable tourism, geotourism does not require pristine and unspoiled nature as it's base. A great tour can equally be delivered on a quarry floor or in a historic mining area thus providing relief from the overuse of ecologically sensitive areas (Robinson, 2008).

This paper focuses on the Lazar's Canyon area and nearby geosites which possess great potential for geotourism development. One of the aims of this paper is to raise awareness about this destination by making an inventory of the most attractive geosites in the area and by presenting their values to a wider auditorium. One of the key elements for the inclusion of this area in future tourism flows is the process of tourist evaluation which must not be focused only on the expert's opinion but also on the opinion of visitors and tourists. In the final part of the paper we also briefly discuss and analyze the criteria necessary for the declaration of a Geopark in this area.

\section{An overview of previous evaluation models}

The assessment methods developed in previous years focused mainly on geomorphosites and their scientific quality, and later additional values (Grandgirard, I999; Bruschi, Cendrero, 2005; Coratza, Giusti, 2005; Reynard, 2005; Reynard, Panizza, 2005; Reynard, et al., 2007; Pereira, et al., 2007; Vujičić, et al., in press). Based on some of these methods, a new model was developed by Pralong (2005) specifically for the evaluation of the tourist quality of geomorphosites and their use by the tourism sector. According to this method, the tourist value of a site is determined as the average value of the scenic, scientific, cultural and economic values. In this model, like in many earlier models, one of the main issues concerning the evaluation of a site is objectivity. None of the mentioned methods include information on the needs, views, interests and aspirations of the tourists that visit geosites which is very important especially when evaluating the tourist potential of a site. Visitor inclusion in the evaluation process is a good way to achieve objectivity. An example of this is given in a report by the Scottish Natural Heritage (George Street Research, 2006). The report describes a survey conducted among regular visitors (non-experts) and experts thus including the opinion of both ends of the spectrum instead of just one like in most previous models. However, this type of research can be complex and time consuming which means that the development of more simple methods is required for the future selection of the best sites for geotourism.

\section{Methods and data}

For the purpose of this paper we used the evaluation model proposed by Hadžić et al. (20I0), at the international conference on geoheritage and geotourism "Geotrends 20Io". This model is based on the following facts:

The term geoheritage presents a synthesis of several elements: socio-cultural, historical, scenic, archaeological, educational, scientific, fun, psychological and artistic (geosites and landscapes have always been source of inspiration of painters, sculptors, writers and musicians).

Geotourists have different profiles with respect to their motivation (Hose, 1994; Pralong, 2006) for the visit of a geosite: some are interested in specific fields of the Earth sciences and possess excellent knowledge in these fields while others are motivated by a large socio-cultural or artistic interest. The sites with the best visible remains and high scien- 
tific values are not necessarily the best from the point of view of tourists who are interested very much in socio-cultural meanings of a geosite. Static displays of mining remains are unlikely to attract much more than academic interest. Visitors want to become actively involved during their visit and the fun factor must not be underestimated. Hence, the importance of some subindicators in the model is strongly related to the specific need of a specific segment of geotourists. The structure and size of tourist segments is changeable over time. It may be that in certain periods of time visitors of a geosite are mostly interested in the scientific value of a geosite, but later on, a large part of visitors can belong to a segment of tourists who are mostly interested in the socio-cultural meaning of a geosite. Hence, the market value of a geosite (estimated by the number of visitors and the revenues of taxation) depends on many variables. Despite the importance of the fun factor, the need for conservation and general education about the sustainable development principles should also be considered. It is necessary to take into account the principles of sustainable development of tourism such as the interest of the local community and the preservation of natural heritage. Hence, the number of visitors of a fragile geosite is limited by the carrying capacity of the geosite.

The value and importance of a geosite is determined by the evaluation of three indicators - scientific value (table I), additional values (table 2) and the required protection which is connected with the level of deterioration and vulnerability. This model also provides a possibility for geosite comparison based on the final results of the evaluation (Hadžić, et al., 20Io).

Table 1. Subindicators for scientific value [ScV]

\begin{tabular}{|c|c|c|}
\hline \multirow{8}{*}{$\begin{array}{l}\text { Scientific } \\
\text { Value } \\
{[\mathrm{ScV}]}\end{array}$} & Rareness in relation to the area & $\mathbf{R a}$ \\
\hline & Integrity & In \\
\hline & $\begin{array}{l}\text { Representativeness of } \\
\text { geomorphological processes }\end{array}$ & Rp \\
\hline & $\begin{array}{l}\text { Diversity of geomorphological } \\
\text { features }\end{array}$ & Dv \\
\hline & $\begin{array}{l}\text { Other geological features with } \\
\text { heritage values }\end{array}$ & Ge \\
\hline & Scientific knowledge & Kn \\
\hline & Educational interest & Ed \\
\hline & Rareness at the national level & $\mathbf{R n}$ \\
\hline
\end{tabular}

Scientific value $(\mathrm{ScV})$ is calculated as follows:

$\mathrm{ScV}=\operatorname{Im}(\mathrm{Ra}) \mathrm{xRa}+\operatorname{Im}(\operatorname{In}) \mathrm{x} \operatorname{In}+\operatorname{Im}(\mathrm{Rp}) \mathrm{xRp}+$ $\operatorname{Im}(\mathrm{Dv}) \mathrm{xDv}+\operatorname{Im}(\mathrm{Ge}) \mathrm{xGe}+\operatorname{Im}(\mathrm{Kn}) \mathrm{xKn}+$ $\operatorname{Im}(\mathrm{Ed}) \mathrm{xEd}+\operatorname{Im}(\mathrm{Rn}) \mathrm{xRn}$

The importance of every subindicator (Im) is evaluated by tourists (from o to I). That number is then multiplied with the value that is given by experts (from I to 5) for that same subindicator. This is done for each subindicator and afterwards the values are added up and the final result is the scientific value of a geosite. This is a good way of actively including tourists and their opinion in the evaluation process.

Table 2. Subindicators for additional values [AdV]

\begin{tabular}{|c|c|c|}
\hline \multirow{13}{*}{$\begin{array}{l}\text { Additional } \\
\text { values } \\
{[\mathrm{AdV}]}\end{array}$} & Scenic value & ScV \\
\hline & Ecological value & Ec \\
\hline & $\begin{array}{l}\text { Experience component of a } \\
\text { geotourism product }\end{array}$ & Ex \\
\hline & $\begin{array}{l}\text { Representativeness for the } \\
\text { destination }\end{array}$ & $\operatorname{ReD}$ \\
\hline & $\begin{array}{l}\text { Connection with some artistic } \\
\text { work }\end{array}$ & AW \\
\hline & $\begin{array}{l}\text { Connection with the social } \\
\text { development of the local } \\
\text { community }\end{array}$ & DLC \\
\hline & $\begin{array}{l}\text { The possibility to organize some } \\
\text { special cultural events }\end{array}$ & OCE \\
\hline & $\begin{array}{l}\text { Interpretative value [connected } \\
\text { with a "good story"] }\end{array}$ & In \\
\hline & $\begin{array}{l}\text { Existence of complementary } \\
\text { natural and cultural heritage }\end{array}$ & Com \\
\hline & $\begin{array}{l}\text { The quality of management of the } \\
\text { geosite }\end{array}$ & Qu \\
\hline & Equipment and support services & Ess \\
\hline & Accessibility & Acc \\
\hline & Visibility & Vi \\
\hline
\end{tabular}

Additional values (AdV) are calculated in the same way as scientific value by multiplying the importance (Im) of each subindicator which is assessed by tourists (from o to I) with the value for that same subindicator that is given by experts (from I to 5).

$$
\begin{aligned}
\mathrm{AdV}= & \operatorname{Im}(\mathrm{ScV}) \mathrm{xScV}+\operatorname{Im}(\mathrm{Ec}) \mathrm{xEc}+\operatorname{Im}(\mathrm{Ex}) \mathrm{xEx}+ \\
& \operatorname{Im}(\mathrm{ReD}) \mathrm{ReD}+\operatorname{Im}(\mathrm{AW}) \mathrm{xAW}+ \\
& \operatorname{Im}(\mathrm{DLC}) \mathrm{xDLC}+\operatorname{Im}(\mathrm{OCE}) \mathrm{xOCE}+ \\
& \operatorname{Im}(\operatorname{In}) \mathrm{xIn}+\operatorname{Im}(\mathrm{Com}) \mathrm{xCom}+\operatorname{Im}(\mathrm{Qu}) \mathrm{xQu}+ \\
& \operatorname{Im}(\text { Ess) } \mathrm{x} \text { Ess }+\operatorname{Im}(\text { Acc }) \mathrm{xAcc}+\operatorname{Im}(\mathrm{Vi}) \mathrm{xVi}
\end{aligned}
$$

The last indicator, which does not have any subindicators, is the vulnerability of the geosite $(\mathbf{V u})$ which is evaluated only by experts (from I to 5 , where I represents a high level of vulnerability and 5 represents a high level of robustness).

The final result of the tourist evaluation (TE) is obtained by adding up the scientific value, additional values and the vulnerability of the geosite $T E=S c V+A d V+V u$.

As it was said before, there have been many evaluation models over the years but this one seems to be one of the simplest and the most objective 
model as it considers not only the views and opinions of experts but also the views of visitors whose needs and interests have a significant impact in determining the value and potential of a geotourism destination. The evaluation of some subindicators (for example scenic value) can be very subjective and a survey among visitors is a good way to avoid such a problem.

Another challenge is the selection of criteria that allow an objective evaluation of a geosite. It is not enough to only consider the scientific value of a geosite since the visitors are usually not all from the scientific community. It is important to consider other domains of human and natural history such as the scenic, ecological, cultural and other nonscientific values. These values need to be incorporated in the evaluation process and that is why the presented model has several additional values alongside the scientific value of a geosite. This way we can completely evaluate the quality of a site and it's potential for tourism development.

\section{Geodiversity of Lazar's Canyon - A Proposed Inventory of Attractive Geosites}

There have been many definitions of geodiversity through time, but the most commonly used definition is the one given by Gray (2004) who defines geodiversity as "the natural diversity of geological, geomorphological and soil features. It includes their assemblages, relationships, properties, interpretations and systems."

Based on an agreement at the ProGEO level and the adopted classification of geosites, (Wimbledon, I996) the area of Lazar's Canyon falls within the category of geomorphologic sites with it's canyons, caves and other karst features. This area possesses a large number of geosites on a relatively small teritorry making it one of the areas with the highest concentration of geosites in the country.

Lazar River Canyon is one of the deepest, most inhospitable and impassable canyons in Serbia (Figure 2) with a length of 4400 meters and an average incline of the longitudinal profile of $44 \%$.

The greatest depth of the canyon is at the Kovej site, where on the right side of the valley, the upper edge of vertical cliffs is at 375 meters above the canyon bottom, and on the left side the depth is 330 meters. The canyon bottom narrows in some places between three and four meters and throughout the canyon there is a great number of boulders (Figure 3), rocky towers and cascades that ocasionally turn into waterfalls. The most prominent rock tower is located at the juncture of Mikulj River Canyon and Lazar's Canyon. The height of this tower is 150 meters (Figure 4) (Lazarević, 1998).

Mikulj River Canyon represents the first, left constituent of Lazar's Canyon, which in it's final,

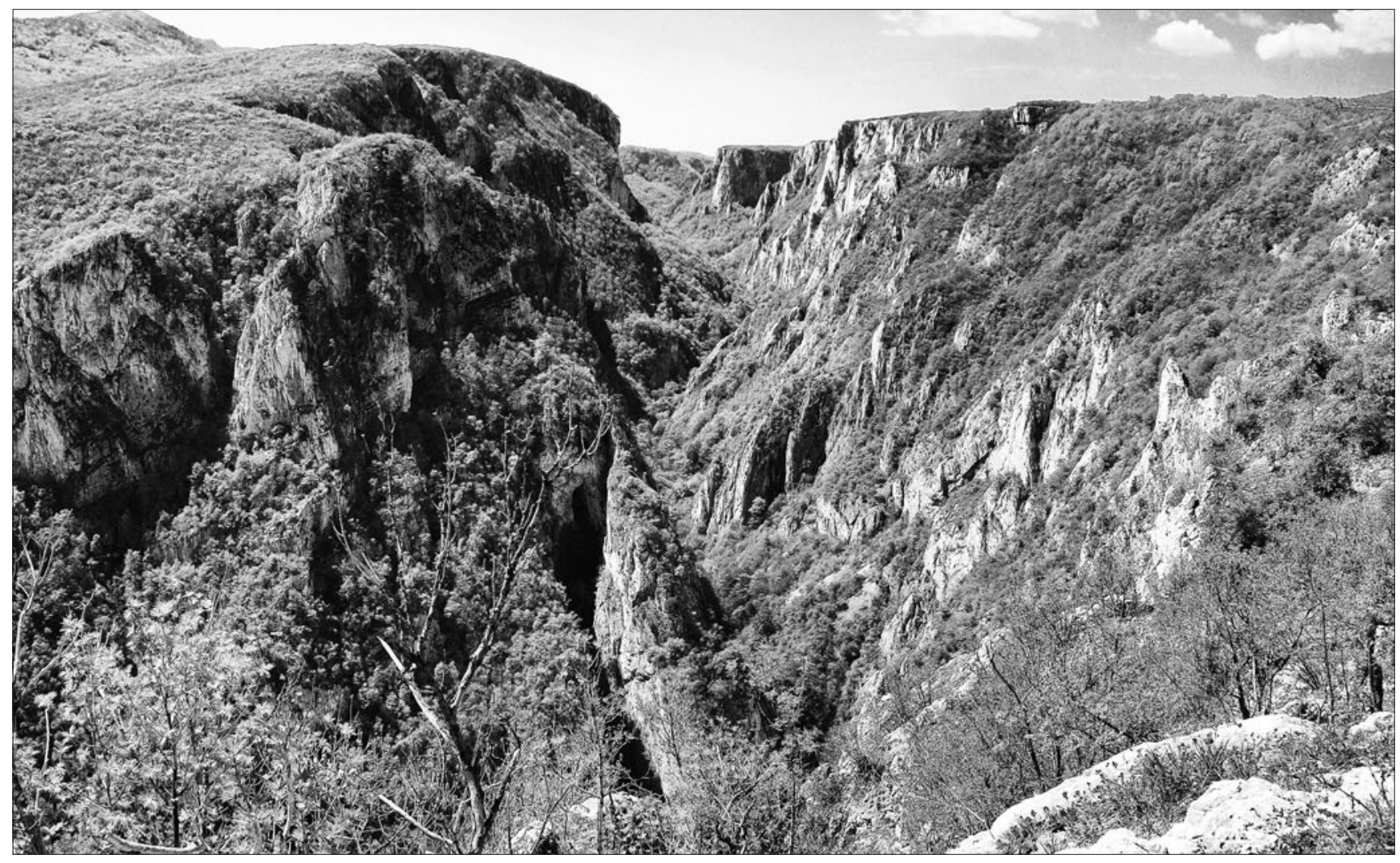

Figure 2. Lazar's Canyon view from the Grand viewpoint

Source: www.freebiking.org 
approximately 2.5 kilometers long section (downstream from the dirt road) has the features of a canyon with vertical rocky walls from 60 to 150 meters deep and the width between the upper edges from 70 to 80 meters in some places. The canyon gap is in it's winding, meander part, I.5 meters wide in several places (Vasiljević, et al., I998).

Demižlok River Canyon is a fossil canyon whose length is I.3 kilometers, from the sink to the Pojenska River valley. The fossil canyon (Figure 5) is 20 meters above the sink which is at an altitude of 637 meters. According to the local residents and their stories, the last time that Demižlok flowed through the fossil canyon was in the second half of the Igth century (Lazarević, I998).

Vej River Canyon. During the summer period, when there is less water, the Vej River plunges into gapes and cracks that are connected to diastromes. During the wet period of the year, the Vej River flows along it's entire length, and then, by using the Lazar's River bed it reaches the mouth of the Zlot River. Unlike the Mikulj and Demižlok River, the Vej River has a continuous longitudinal profile since it has a constant or periodical flow (Lazarević, 1998).

Malinik Mountain is located on the right side of Lazar's Canyon in the shape of a prominent ridge expanding from northeast to southwest, reaching maximum height at it's isolated conical hill called Veliki Malinik, II5 8 meters above sea level. It's northern steep side and it's highest peak are built mainly from Paleozoic shales, while

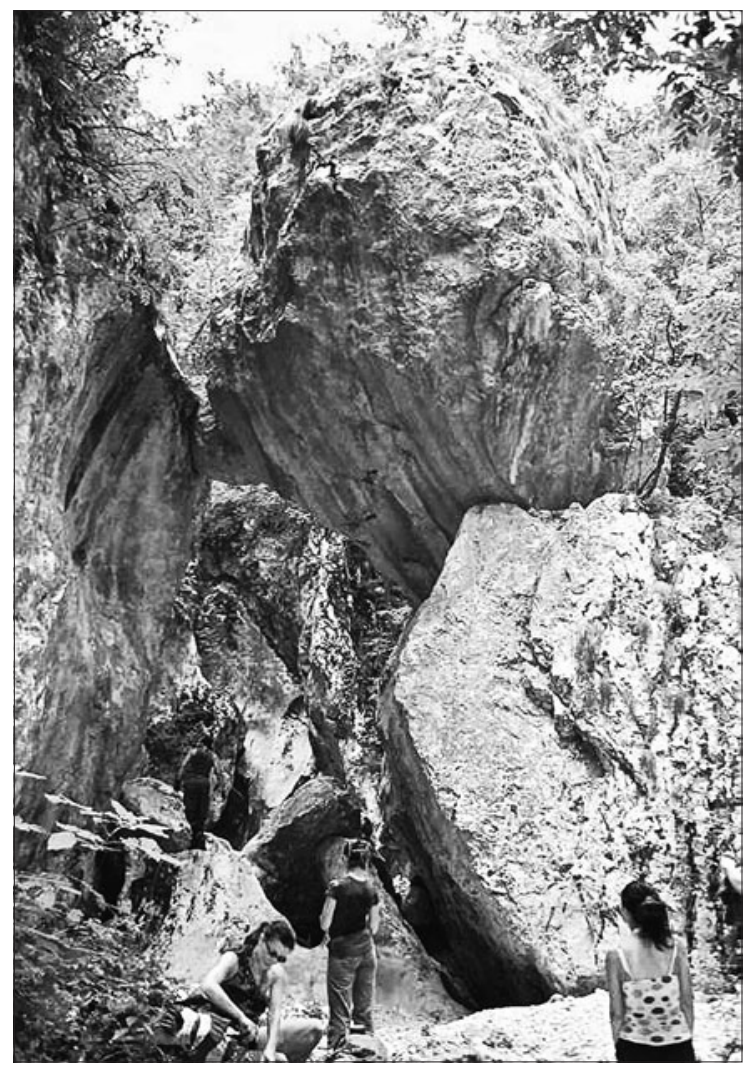

Figure 3. Rocks and boulders at the canyon entrance Source: www.freebiking.org

the northeastern side is made out of limestone. The southeastern slopes of Mali Malinik are covered with foliated metamorphic rocks (Figure 6) (Vasiljević, et al., I998).

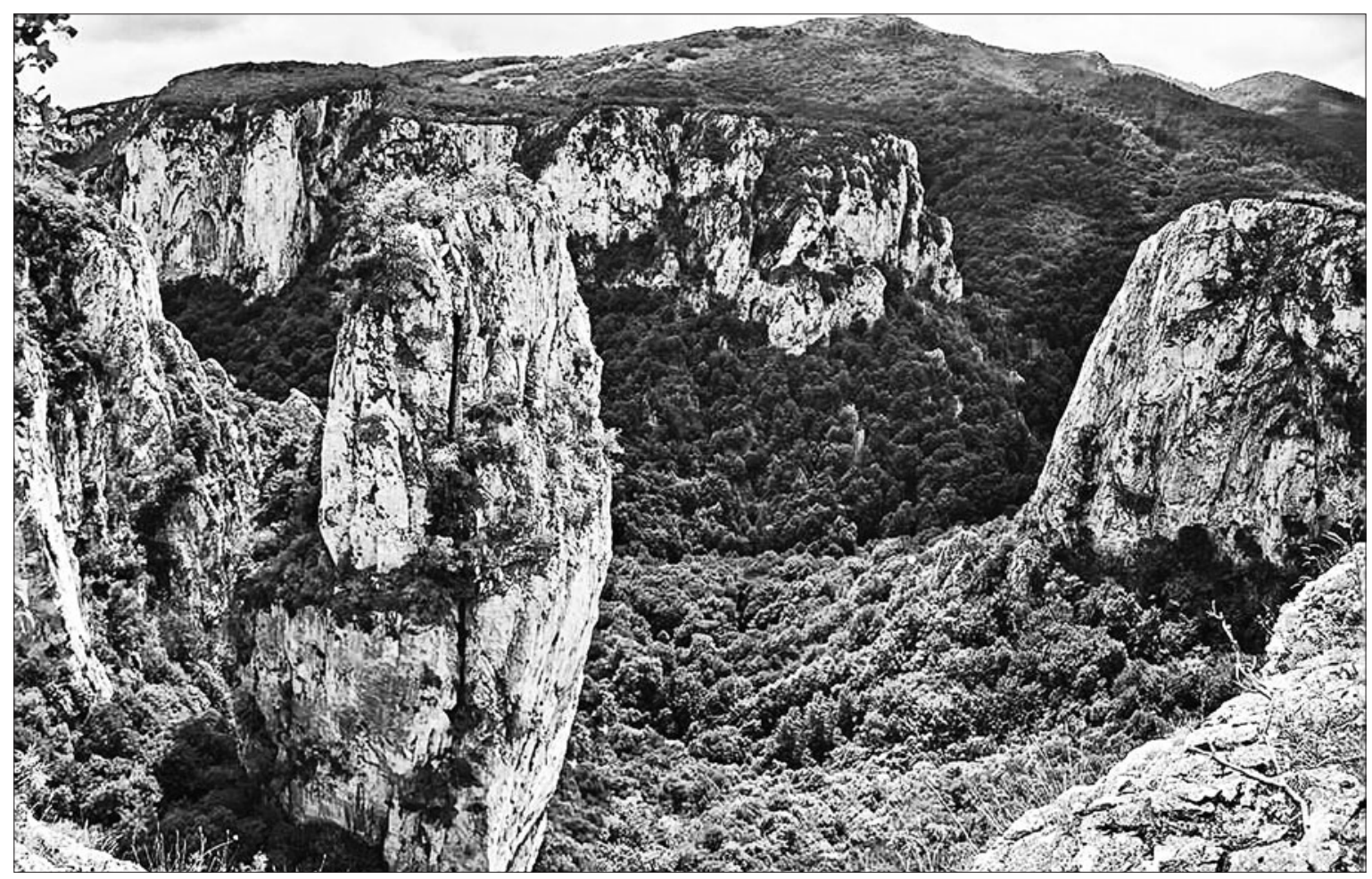

Figure 4. The rock tower located at the junction of Mikulj River Canyon and Lazar's Canyon

Source: www.freebiking.org 


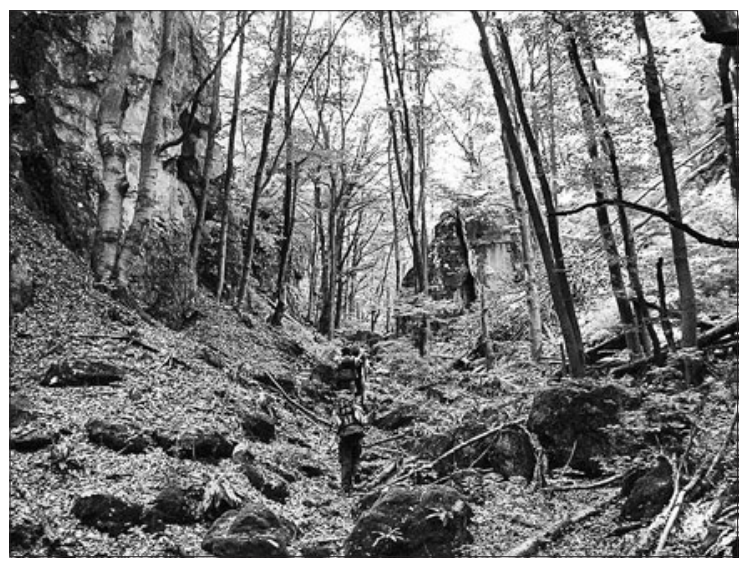

Figure 5. The fossil canyon of Demižlok Source: www.freebiking.org

Lazar's Cave is located downstream, at the end of Lazar's Canyon, 6.70 meters above the Lazar River bed. The total length of the explored part of the cave is 1592 meters of which I225 meters belongs to the dry channels (Vasiljević, et al., I998).

The backbone of the cave's channel system is the main channel with several larger morphological units: Prestona hall with the Cathedral of blocks in the nortwestern branch, and a Concert hall and the Hall of bats near the end of the north branch. Besides it's length, there are several other indicators that show the significance of this cave: It's surface area is 9900 square meters and it's volume is around 70000 cubic meters of which the main channel takes about 52000 meters. The cave has very rich ornaments made from calcite and travertine that vary in shape, size and color (Lazarević, 1978). It also has paleontological remains of Ice Age animals as well as 5000 years old archaeological remains of tools and pottery (Vasiljević, et al., 1998).

Vernjikica Cave is located in the left side of Lazar's Canyon, below the Kornjet elevation at 545.5 meters above sea level and over 150 meters above the canyon bottom.

The total length of the cave is Ior5 meters, it's surface area is 13000 square meters and it's volume is 260000 cubic meters, calculated for the average height of 20 meters.

The Colosseum hall is the best proof of this cave's megalitic dimensions. The diameter of this rounded room is over 55 meters, and the maximum height of it's dome ceiling is 50.7 meters, while the height difference between the lowest point on the floor and the highest point on the ceiling is 58.7 meters (Lazarević, I998).

This cave is also characterised by vast amounts of calcite and crystal accumulation, which form extremely diverse and imposing figures like the stalagmite Colossus, which is the symbol and logo of Vernjikica with a height of II.5 meters.

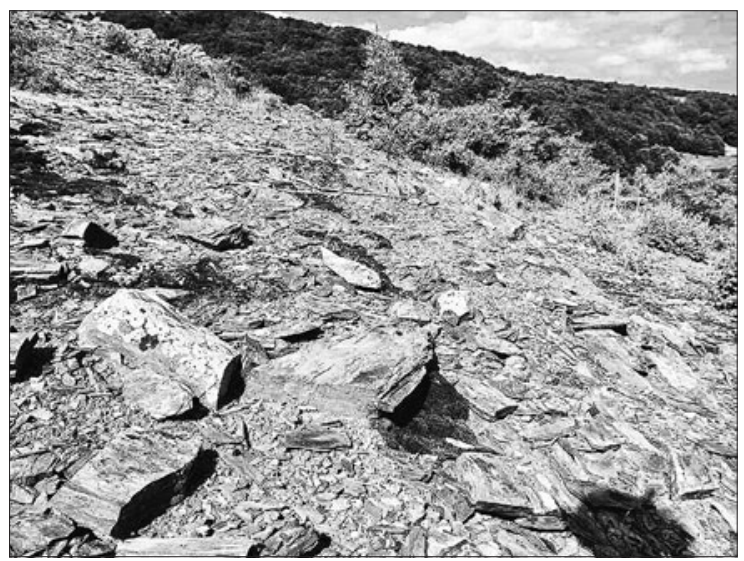

Figure 6. Foliated metamorphic rocks of Mali Malinik Source: www.freebiking.org

\section{Results and discussion}

(Geo)tourist evaluation of Lazar's Canyon. For the purposes of the evaluation of Lazar's Canyon, according to the presented model, a small survey was conducted among the visitors of the canyon in late August when three smaller groups of tourists visited the site and filled out a questionnaire afterwards. The questionnaire consisted of 2I questions/subindicators and each visitor was asked to evaluate the importance of every subindicator by rating it from zero to one. A total of 80 visitors filled out the questionnaire on the spot.

Scientific value, additional values and vulnerability of Lazar's Canyon are presented in the following text according to the earlier explained model and the results of the survey.

$$
\begin{aligned}
\mathbf{S c V}= & 0,94(\mathrm{Ra}) \times 5+0,90(\mathrm{In}) \times 5+0,69(\mathrm{Rp}) \times 5+ \\
& 0,70(\mathrm{Dv}) \times 5+0,76(\mathrm{Ge}) \times 5+0,67(\mathrm{Kn}) \times 3+ \\
& 0,80(\mathrm{Ed}) \times 3+0,6 \mathrm{I}(\mathrm{Rn}) \times 5=24,3 \\
\mathbf{A d V}= & 0,89(\mathrm{ScV}) \times 5+0,70(\mathrm{Ec}) \times 5+0,80(\mathrm{Ex}) \times 3+ \\
& 0,77(\mathrm{ReD}) \times \mathrm{I}+0,69(\mathrm{AW}) \times \mathrm{II}+ \\
& 0,52(\mathrm{DLC}) \times 2+0,89(\mathrm{OCE}) \times \mathrm{xI}+0,82(\mathrm{In}) \times 3+ \\
& 0,64(\mathrm{Com}) \times 5+0,73(\mathrm{Qu}) \times 3+0,73(\mathrm{Ess}) \times 2+ \\
& 0,73(\mathrm{Acc}) \times 3+0,73(\mathrm{Vi}) \times 5=28,89 \\
\mathbf{V u}= & 2
\end{aligned}
$$

The final result of the evaluation (TE), after adding up scientific value, additional values and vulnerability is: $T E=24,3+28,89+2=55,19$

Based on the final results of the evaluation, it can be concluded that the area of Lazar's Canyon possesses a moderate scientific value, less additional values and a high level of vulnerability. With a better organization of tourism activities in the future and with a better understanding and respect for sustainable development principles, it is possible to successfully include this area in future tourism flows.

This canyon is unique in the region and that is one of the reasons it received such a high rareness value from experts but also from visitors which 
indicates that the rareness of the canyon is one of the main reasons for visiting this geosite along with the scenic value and integrity which are also highly rated. The scenic value is higly rated because of beautiful landscapes that are unique to this part of the country and can be experienced from a large number of viewpoints in the area. Ecological value is also higly rated and the reason for this is the rich biodiversity of the area with a large number of endemic and relict plant species. The flora of this relatively small area represents approximately $20 \%$ of the country's flora. Educational interest, scientific knowledge and interpretative value are all moderately rated which indicates that the educational values of the canyon are not the most important factor for visiting, but nevertheless, education still plays an important role for some of the visitors. High quality interpretation is a very important factor for geotourism development and it should be given much more attention in the future. Better trained guides and the establishment of museums and interpretive centers is required. Among the lowest rated subindicators is the representativeness of the canyon for the destination and it's connection with the social development of the local community. The reason for this is the unrecognizability of the canyon. Apart from a small number of people that visit it, the majority does not know where the canyon is located or even that it exists. This can be rectified by better promotional activities and with greater involvement of the local community in this and every other tourist activities. The local community is still not very interested in tourism activities and is unaware of the great potential that this area holds as a potential geotourism destination. Better education and promotion is required among the local community in order to raise awareness about the potential of this area. This can be done with the help of the local and regional tourism organisations.

The combination of a unique landscape and a rich ecosystem with geosites of certain scientific and educational value is particularly interesting from the view point of tourism promotion. Not only will this destination be a good alternative for tourists that have already visited other similar geosites, it may also capture the interest of those who have little or no knowledge of the earth sciences.

\section{Lazar's Canyon - Future Geopark?}

The area of Lazar's Canyon as a whole, was first protected by the law regulating the field of nature conservation and natural resources. There were two separate areas within the area of Lazar's Canyon that were protected earlier, based on the law on protection of cultural monuments and natural rarities. Those areas were the Natural monument "Lazar's Cave", protected in I949. and the reserve "Malinik" protected in I957 (Vasiljević, et al., I998).

In the year 2000 , due to its great importance, Lazar's Canyon was put under state protection as a monument of nature of the first category with a second degree protection regime. The surface of the protected area is 1755 hectares.

At the beginning of the twentieth century, $U N$ ESCO introduced and developed a new concept of a protected area called a Geopark with the emphasis on the protection and promotion of geodiversity, education and interpretation of geoheritage, improvemet of socio-economic status of the local community and the improvement of environmental protection through the development of geotourism. Therefore, a geopark is a territory which includes a sustainable territorial development strategy with clearly defined boundaries and with rich geodiversity and various geoheritage sites and also rich natural, cultural and historical heritage (www.europeangeoparks.org).

By the definition of Geoparks, which is taken to mean that it is a territory with significant geoheritage where geotourism is developed in cooperation with the local community, but also an experimental territory within the thematic network, it can be concluded that the area of Lazar's Canyon can be declared as a Geopark in the future. In order for a territory to become a Geopark, it must meet several criteria: size and setting, management and local involvement, economic development, education, protection and conservation, the global network (www.europeangeoparks.org).

The area of Lazar's Canyon and it's surroundings already meets some of the necessary criteria but not all. It is important to put in more effort from the nature protection community and other relevant organisations in the future so that this area completely meets all of the required criteria for becoming a Geopark.

This territory already possesses a sufficient number of geoheritage sites that are beautiful, rare and have a certain scientific value. Because of these facts, it is already protected on a national level as a natural monument with clearly defined boundaries which is one of the prerequisites for becoming a Geopark. The protected territory is large enough to support a strategy of sustainable development mostly through tourism and the area also has many places with archaelogical, ecological, historical and cultural values that should also be included in future tourism activities.

One of the criteria is also the establishment of a governing body and a plan for further management of the area. Future efforts should be concentrated on the establisment of a destination management organization which would employ a team 
of tourism managers that would deal with the planning and managing activities of the Geopark. This team has to be able to identify a series of appropriate actions that need to be efficient and effective and to determine when, by whom and at what cost will these actions be implemented. The destination management organization must have adequate managing infrastructure, financial support and quality staff at it's disposal. The establishment of a management plan is followed by it's application in practice and constant monitoring and quick prevention of potential problems. An integral part of the planning process is the local community which must be properly included in all plans along with other stakeholders who also need to be involved in the decision making process.

One of the main strategic goals of a Geopark is to stimulate both the socio-economic activity and sustainable development by creating local enterprises and small businesses while at the same time respecting the environment which would in turn provide new jobs and revenue while protecting natural resources. It is important to find a balance between economy and ecology which is not always easy. A good example of how to do this is the Network History of Earth, initiated in Germany in 1997. by the Chair of Applied Geography (University of Tübingen). This network includes a large number of stakeholders from various different fields who were brought together by a common interest which resulted in the forming of a very heterogeneous network (Newsome, Dowling, 20Io). This type of activity and cooperation is currently imperceptible and almost non-existent in the Lazar's Canyon area. All relevant stakeholders can't seem to find a common language and a common interest which would lead them towards cooperation and succesful partnership.

Another criterion is the education of Geopark visitors which must be organized in such a way that visitors can successfully receive knowledge about geosites. This can be achieved through various museums, interpretive and educational centers, trails, guided tours, popular literature and maps, modern media etc. Web-based dynamic maps can be a great educational tool and also an excellent way of promoting a geotourism destination (Vasiljević, et al., 2009). The use of these maps can very effectively contribute to the marketing of Lazar's Canyon in the future. Interpretation and education are the main values which should animate and inform the potential visitors of Lazar's Canyon. Interpretation plays a crucial part in how people experience the places they visit as it explains geological heritage and brings it to life. Depending on the location of their implementation, interpretative methods can be divided in two categories, in situ (implemented at the geosites in forms of paths, panels, tours, etc.) and ex situ (used in related facilities like visitor centers) (Vasiljević, et al., in press). The interpretation of the Lazar's Canyon geosite and the education of it's visitors are not at a high level for the time being but this could change very easily in the future with a better implementation of the aforementioned activities.

Geopark authorities should provide protection and conservation of the geoheritage within the park in accordance with local tradition and legislative obligations. The government of the country in which the park is located is the one that decides about the level and measures of protection of certain areas or geological profiles. Monument of nature "Lazar's Canyon" is currently being looked after by the Public Enterprise for Forest Management "Srbijašume" from Belgrade, Lumber Camp "Timočke šume" from Boljevac and the Forest office "Bor".

These three organizations, or any one of them, should establish a team or a smaller organization which would be strictly focused on the protection and conservation of this area.

In order to show that the rules about managing and protecting geoheritage apply equally to all, the Geopark governing body must not in any way participate in the sale of geoheritage and geosites within the park area and it should also be against the unsustainable trade of geological material in general, including the sale of Earth heritage, minerals and fossils. On the other hand, it should allow, under certain circumstances, restricted (sustainable) collection of geological specimens for scientific and educational purposes from renewable natural sites within the Geopark (www.europeangeoparks.org).

Along with the aforementioned criteria, it is also necessary to include this potential Geopark area in the global Geopark network which enables cooperation between experts and practitioners in geological heritage matters. This international partnership developed by UNESCO, brings the advantage to be a member of and profit from a worldwide network, as compared to a local isolated initiative. It permits to benefit from the experience of other members of the network (www.europeangeoparks.org).

\section{Conclusion}

At the moment, the Lazar's Canyon area fully meets only the basic criterion needed for the declaration of a Geopark. It possesses a sufficient number of geosites and a substantial territory for the implementation of a sustainable development strategy. The criterion that is partially met, is the establishment of a governing body for the management of the protected area. This body should actively include the local community in future 
planning and should also provide the necessary infrastructure needed for further development of geotourism. Several criteria are completely unfulfilled. The economic development of this area is extremely low, almost non-existent. The education of visitors is also on a very low level due to the lack of adequate infrastructure and qualified staff who should be engaged in education and interpretation. The protection and conservation of the area is present to a certain extent, but still not high enough. Stricter enforcement of already established protection measures is necessary in the future.

Finally we can conclude that the Lazar's Canyon area has great geodiversity which makes it attractive for various types of tourism, including geotourism. Even though it possesses good potential for geotourism development, the canyon currently meets only the basic requirements needed for the declaration of a Geopark. This situation can be changed relatively easily in the future with better quality organization that would be strictly targeted on fully meeting other necessary criteria. With proper promotional activities, Lazar's Canyon could become a new destination of geotourism and a brand of eastern Serbia, in the same way as Devil's town is a well-known geotourism destination, brand and symbol of southern Serbia.

\section{Acknowledgements}

This work was partly supported by Project \#I76020 of the Serbian Ministry of Science and Technological Development. The author would also like to thank Aleksandar Veljković for pleasant cooperation and for providing great photographs that have contributed to improve this manuscript.

\section{References}

Bruschi, V.M., Cendrero, A. 2005. Geosite evaluation. Can we measure intangible values?. $\mathrm{Il}$ Quaternario I8, I, 293-306.

Burek, C.V., Prosser, C.D. 2008. The history of geoconservation: an introduction. Geological Society, London, Special Publications, pp. I-5.

Coratza, P., Giusti, C. 2005. Methodological proposal for the assessment of the scientific quality of geomorphosites. Il Quaternario I8, I, 307313.

Djurović, P., Mijović, D. 2006. Geoheritage of Serbia-Representative of it's total geodiversity. Collection of papers 54, 5-18. (in Serbian)

Dowling, R.K. 2008. The emergence of geotourism and geoparks. Journal of Tourism 9, 2, 227236.

Dowling, R.K., Newsome, D. 2010. Global Geotourism Perspectives. Goodfellow Publishers Ltd, Oxford, 266 pp.
George Street Research 2006. Geotourism in Scotland - evaluation and development. Phase 2 Knockan Crag customer survey. Scottish Natural Heritage Commissioned Report No. 170 (roame no. Fo4ACio4/2).

Grandgirard, V. 1999. L'évaluation des géotopes. Geologia Insubrica 4, 59-66.

Gray, M. 2004. Geodiversity: Valuing and Conserving Abiotic Nature. John Wiley and Sons Ltd, Chichester, $434 \mathrm{pp}$.

Hadžić, O., Marković, S.B., Vasiljević, Dj.A., Nedeljković, M. 20Io. A Dynamical Model for Assessing Tourism Market Attractiveness of a Geosite. Ist International Conference on Geoheritage \& Geotourism Research GEOTRENDS 20I0, Novi Sad 24-26 June 20Io. Abstract book: 23-25.

Hose, T.A. I994. Telling the story of stone - assessing the client base. D. O'Halloran, C. Green, M. Harley and J. Knill (Eds.), Geological and Landscape Conservation, Proceedings of the Malvern International Conference I993, Geological Society, London, 45I-457.

Hose, T.A. I995. Selling the story of Britain's stone. Environmental interpretation I0, 2, I6-I7.

Hose, T.A. 2003. Geotourism in England: A TwoRegion Case Study Analysis. Unpublished PhD thesis, University of Birmingham, Birmingham, UK.

Hose, T.A. 2005. Geo-Tourism - Appreciating the deep side of landscapes in Novelli. Niche tourism; contemporary issues, trends and cases, Elsevier Science Ltd., Oxford, UK, pp. 27-37.

Hose, T.A. 2008. Towards a history of Geotourism: definitions, antecedents and the future in Burek, C.V. \& Prosser, C.D. The History of Geoconservation. Geological Society of London, London, UK, pp. 37-6o.

Lazarević, R. I978. Zlot Caves. Tourist organization of Bor, Bor. (in Serbian)

Lazarević, R. 1998. Karst of Dubašnica, Gornjan and Majdanpek. Serbian geographical society, Belgrade, 302 pp. (in Serbian)

Newsome, D., Dowling, R.K. 2010. Geotourism: The Tourism of Geology and Landscape. Goodfellow Publishers Ltd, Oxford, 260 pp.

Pereira, P., Pereira, D., Caetano Alves, M.I. 2007. Geomorphosite assessment in Montesinho Natural Park (Portugal). Geographica Helvetica 62, 159-168.

Pralong, J.-P. 2005. A method for assesing the tourist potential and use of geomorphological sites. Géomorphologie: relief, processus, environnement 3, I89-196.

Pralong, J.-P. 2006. Research approaches concerning the guiding image of "Protection through Use" in geoparks and geotouristic destinations. Regionalwissenschaftliche Forschung 3I, 5I-55. 
Reynard, E. 2005. Géomorphosites et paysages. Géomorphologie: relief, processus, environnement 3, I8I-I88.

Reynard, E. and Panizza, M. 2005. Geomorphosites: definition, assessment and mapping. An introduction. Géomorphologie: relief, processus, environnement 3, I77-I80.

Reynard, E., Fontana, G., Kozlik, L., Scapozza, C. 2007. A method for assessing the scientific and additional values of geomorphosites. Geographica Helvetica 62/3, I48-I58.

Robinson, A. M. 2008. Geotourism: Who Is a Geotourist?. Australia's Ist Conference on Green Travel \& Climate Change is taking Shape, Adelaide, Australia.

Vasiljević, B., Šehovac, E., Lakušić, D., Ostojić, D., Grubač, B., Simonov, N. I998. Case study: Proposal for protection of natural monument " $\mathrm{La}$ zar's Canyon" as a natural resource of great importance. Institute for nature conservation of Serbia, Belgrade. (in Serbian)

Vasiljević, Dj.A., Marković, S.B., Hose, T.A., Smalley, I., Basarin, B., Lazić, L., Jović, G. in press. The Introduction to Geoconservation of loesspalaeosol sequences in the Vojvodina region: Significant geoheritage of Serbia. Quaternary International, doi:Io.IoI6/j.quaint.2010.07.008.
Vasiljević, Dj., Marković, S.B., Hose, T.A., Basarin, B., Lazić, L., Stojanović, V., Lukić, T., Vidić, N., Jović, G., Janićević, S., Samardžija, D. 2009. The Use of Web-Based Dynamic Maps in the Promotion of the Titel Loess Plateau (Vojvodina, Serbia), a Potential Geotourism Destination. Geographica Pannonica I3, 3, 78-84.

Vujičić, M.D., Vasiljević, Dj.A., Marković, S.B., Hose, T.A., Lukić, T., Hadžić, O. In press. Preliminary Geosite Assessment Model (GAM) and Its Application on Fruška Gora Mountain, Potential Geotourism Destination of Serbia. Acta Geographica Slovenica.

Wimbledon W. I996. National site selection, a stop on the road to a European Geosite list. Geologica Balcanica, Special issue Geological Heritage, BAN, 15-28.

http://www.europeangeoparks.org/isite/ page $/ 2, \mathrm{I}, \mathrm{o} . \mathrm{asp} ? \mathrm{mu}=\mathrm{I} \& \mathrm{cmu}=7 \& \mathrm{th} \mathrm{ID}=\mathrm{O}, \mathrm{Ac}-$ cessed: 5 th february $201 \mathrm{I}$

http://www.europeangeoparks.org/isite/ page $/ 8, \mathrm{I}, 0 . \mathrm{asp} ? \mathrm{mu}=4 \& \mathrm{cmu}=26 \&$ thID $=0, \mathrm{Ac}-$ cessed: 5 th February $201 \mathrm{I}$

http://freebiking.org/wpg2?g2_itemId=535, Accessed: 3rd March 20II

http://freebiking.org/wpg2?g2_itemId=693, Accessed: 3rd March 20II 